\title{
Potential of Phytase-Mediated Iron Release from Cereal-Based Foods: A Quantitative View
}

\author{
Anne V. F. Nielsen ${ }^{1}$, Inge Tetens ${ }^{2}$ and Anne S. Meyer ${ }^{1, *}$ \\ 1 Center for BioProcess Engineering, Department of Chemical and Biochemical Engineering, \\ Technical University of Denmark, 2800 Kgs. Lyngby, Denmark; E-Mail: avfn@kt.dtu.dk \\ 2 Division of Nutrition, National Food Institute, Technical University of Denmark, 2860 Søborg, \\ Denmark; E-Mail: intet@food.dtu.dk
}

* Author to whom correspondence should be addressed; E-Mail: am@kt.dtu.dk; Tel.: +45-45-252-909; Fax: +45-45-932-906.

Received: 12 April 2013; in revised form: 1 July 2013 / Accepted: 17 July 2013 /

Published: 2 August 2013

\begin{abstract}
The major part of iron present in plant foods such as cereals is largely unavailable for direct absorption in humans due to complexation with the negatively charged phosphate groups of phytate (myo-inositol $(1,2,3,4,5,6)$-hexakisphosphate). Human biology has not evolved an efficient mechanism to naturally release iron from iron phytate complexes. This narrative review will evaluate the quantitative significance of phytase-catalysed iron release from cereal foods. In vivo studies have shown how addition of microbially derived phytases to cereal-based foods has produced increased iron absorption via enzyme-catalysed dephosphorylation of phytate, indicating the potential of this strategy for preventing and treating iron deficiency anaemia. Despite the immense promise of this strategy and the prevalence of iron deficiency worldwide, the number of human studies elucidating the significance of phytase-mediated improvements in iron absorption and ultimately in iron status in particularly vulnerable groups is still low. A more detailed understanding of (1) the uptake mechanism for iron released from partially dephosphorylated phytate chelates, (2) the affinity of microbially derived phytases towards insoluble iron phytate complexes, and (3) the extent of phytate dephosphorylation required for iron release from inositol phosphates is warranted. Phytase-mediated iron release can improve iron absorption from plant foods. There is a need for development of innovative strategies to obtain better effects.
\end{abstract}


Keywords: phytic acid; phytate; haem iron; non-haem iron; bioavailability; absorption

\section{Introduction}

Iron deficiency anaemia is the most common nutrition deficiency disorder worldwide and a problem in both developed and developing countries. Low iron intakes and poor iron absorption from the diet are common causes of anaemia with women of the child-bearing age, pregnant mothers, adolescents and the elderly being particularly susceptible [1]. Uptake of non-haem iron from plant foods is lower than that of haem iron from meat products. The main inhibitor of non-haem iron absorption in plant foods is phytic acid (myo-inositol $(1,2,3,4,5,6)$-hexakisphosphoric acid). The phosphate groups of phytic acid are negatively charged under physiologically relevant conditions, resulting in phytate chelation of cations such as iron and zinc, making these minerals less available for absorption [2,3]. For vegetarians, elimination of meat coupled with high intakes of phytate-rich whole grains is known to lower iron absorption, increasing the risk of iron deficiency [4]. Analogously, consumption of the recommended daily intake of fibre-rich wheat bread has been found to impair iron status in young women with initially sufficient iron stores [5]. Phytases (mainly enzyme classes E.C. 3.1.3.8, E.C. 3.1.2.26) catalyse release of phosphate from phytate, in turn releasing the chelated minerals. Rather than relying on iron supplements or adding extra iron to foods, e.g., in the form of NaFeEDTA, phytase-catalysed dephosphorylation of naturally present iron phytate chelates in whole grain products is a potential option for increasing bioavailability of iron in the diet. This narrative review will examine the quantitative potential of phytase-catalysed iron release from plant-derived food components, with particular emphasis on the actions of the phytase catalysis in vivo. The text will mainly focus on the phytase-catalysed release of iron from phytate iron complexes present in cereal foods, since cereals and cereal-based meals represent the key plant based staple food type, in which phytate significantly retards or inhibits iron absorption.

\section{Dietary Iron Bioavailability}

Dietary iron generally exists in two forms: Haem iron and non-haem iron. Haem iron constitutes $50 \%-60 \%$ of iron in animal foods, whereas in plant foods the iron is found in non-haem form exclusively [6]. The average bioavailability (defined as the percentage absorption of the total amount of iron in the food) of haem iron is $\sim 15 \%-35 \%$ [7], whereas non-haem iron is much less bioavailable, typically corresponding to $\sim 1 \%-22 \%$ iron absorption [8-11], with cereal-based foods such as porridge having an iron absorption as low as $2 \%-3 \%$ [12].

The low bioavailability of non-haem iron is related to the chemical context of the iron in food. Non-haem iron in plant foods exists in a wide variety of chemical forms, e.g., ferric citrate, ferrous gluconate, ferrous fumarate, ferric dextrans, iron carbonyl, ferritin, ferric phytate, ferrous sulfate, ferrous carbonate, ferric chloride and ferric EDTA [13]. In wheat, the primary storage form of iron has for a long time been believed to be water-soluble monoferric phytate, constituting $\sim 60 \%$ of the wheat bran iron [14,15]. Although a more recent study on wheat grains suggests that most of the iron in wheat is located in ferritin deposits [16] (a storage protein that contains up to 4500 solid mineral iron 
atoms per molecule [17]), the exact level of iron stored this way in wheat and perhaps, other cereals is not known at present. Ferritin iron seems to be readily bioavailable to humans, although the mechanism of absorption is still unclear $[18,19]$.

Generally, iron in foods is in the oxidised ferric form $\left(\mathrm{Fe}^{3+}\right)$, but if not adsorbed or bound to a storage protein, such as in haem iron or ferritin, the ferrous iron form $\left(\mathrm{Fe}^{2+}\right)$ is considered to be the primary form absorbed by humans [13].

It is well established that complexing agents such as ascorbic acid, citric acid, other organic acids, as well as proteins (notably animal proteins from meat) and peptides enhance iron absorption [3,20-22]. Research conducted by García-Casal and co-workers suggests that also vitamin A and beta-carotene may enhance iron absorption $[23,24]$. On the other hand, phytate, tannins, phosphates, polyphenols and antacids inhibit iron absorption [25,26]. However, a fully validated algorithm for accurate prediction of iron bioavailability and absorption is not yet available [27], despite it being much needed, as well as for setting reference values for dietary iron intakes [28].

The absorption-enhancing effect of ascorbic acid is thought to be a result of the reducing properties of ascorbic acid, which reduce the less soluble $\mathrm{Fe}^{3+}$ ion to $\mathrm{Fe}^{2+}$ iron. Apart from being more readily absorbed, the $\mathrm{Fe}^{2+}$ form is also less prone to form complexes with polyphenols or phytate [29]. This redox theory is corroborated by the presence of a putative binding site for ascorbate on duodenal cytochrome-b (Dcyt-b, see Section 5 below on non-haem iron absorption), which catalyses the reduction of $\mathrm{Fe}^{3+}$ to $\mathrm{Fe}^{2+}$ prior to iron transport into the enterocyte [30]. Finally, ascorbic acid acts as a solubiliser, keeping iron in solution in the small intestine, thus enhancing absorption [31] and thereby, further preventing formation of the less soluble ferric phytate complexes [3].

Despite the findings that significant amounts of iron in wheat may be found in ferritin deposits [16], it is widely recognised that phytate is the major inhibitor of iron absorption from plant foods, notably in cereal-based diets [3,5,32-34]. It is not clear whether ferritin iron absorption is also inhibited by phytate, but available data suggests that the influence of phytate on ferritin iron absorption depends on the extent of ferritin degradation [35,36].

It has also been disputed to what extent iron status has an influence on how well haem and non-haem iron are absorbed, respectively, but the current consensus is that haem iron absorption is less affected than non-haem iron by iron status [29]. In any case, it is relevant to consider removal or degradation of phytate, i.e., iron phytate complexes, as a means to improve iron absorption in iron-deficient individuals, particularly in those consuming high amounts of whole grain cereals.

\section{Function, Structure and Properties of Phytic Acid}

Phytic acid (or phytate in the charged form) or myo-inositol $(1,2,3,4,5,6)$-hexakisphosphate (Figure 1) is the phosphorous storage compound in plants, where it accounts for $60 \%-90 \%$ of the seed phosphorous $[3,37]$. 
Figure 1. Structure of monoferric phytate, where $\mathrm{Fe}^{3+}$ is chelated via its six coordination sites. Adapted from [3].

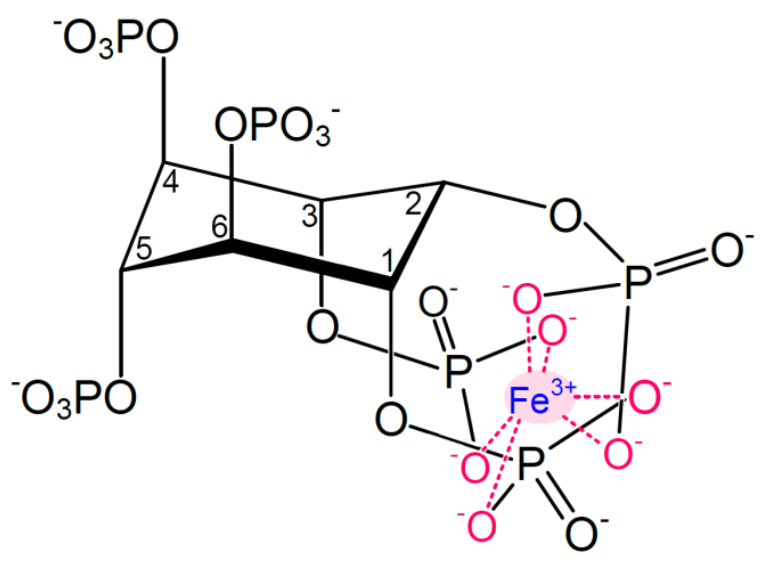

During seed development, phytic acid is deposited as mixed phytate salts of potassium, magnesium, calcium, zinc and iron [38] in globoids; hence, several different cations may be associated with each phytate molecule. Around $\sim 80 \%$ [3] of the globoids are localised in the aleurone layer of most cereal grains, e.g., wheat and barley, whereas in, for example, maize, the globoids are found in the embryo $[2,39]$. Wheat phytate globoids have been found to be constituted of proteins $(46 \% \mathrm{w} / \mathrm{w})$, phytic acid $(40 \% \mathrm{w} / \mathrm{w})$ and minerals in a concentration order of $\mathrm{K}(7.6 \% \mathrm{w} / \mathrm{w})>\mathrm{Mg}(3.2 \% \mathrm{w} / \mathrm{w})>$ $\mathrm{Ca}(0.43 \% \mathrm{w} / \mathrm{w})>\mathrm{Fe}(0.059 \% \mathrm{w} / \mathrm{w})[40]$. At seed maturity, $\sim 15 \%-20 \%$ of the iron in the grain is localised in the pericarp, $\sim 70 \%$ in the endosperm and aleurone layer and $7 \%-8 \%$ in the embryo [41].

At physiologically relevant $\mathrm{pH}$ values $(\mathrm{pH} \sim 1.5-7)$, phytic acid is negatively charged, accounting for the ability of phytate to chelate mineral cations. The more phosphorylated the inositol rings, the stronger the interaction with iron and the lower the solubility. At physiological conditions, i.e., in the intestinal environment, phytate thus forms complexes with ferric iron to form monoferric phytate (Figure 1). The $\mathrm{pK}_{\mathrm{a}}$ values of the phosphate protons corresponding to the carbon numbering in Figure 1 are as follows: $\mathrm{C} 1+\mathrm{C} 3: 1.5$ and 12.0, C2: 1.1 and 6.85, C4 + C6: 2.1 and 10.0, C5: 1.7 and $7.6[42]$.

Monoferric phytate, which is the primary form of iron phytate, is water-soluble, but tetraferric phytate, i.e., phytate chelating four $\mathrm{Fe}^{3+}$ ions is not, indicating that differences in bioavailability of iron from iron phytate complexes may be dependent on solubility of the different stoichiometric versions of iron phytate complexes [15].

Phytate is found in relatively high amounts in plant foods, particularly in cereals and legumes [3]. Daily intake of phytic acid varies largely according to diet from $\sim 0.2-4.6 \mathrm{~g}$ globally, with, e.g., vegetarian diets generally containing higher amounts of phytic acid compared to mixed diets [3,43].

Reported values for iron and phytic acid content in various cereal foods vary widely, but typical values for phytic acid content are in the range of $0.5 \%-1 \%$ by weight (e.g., $[3,43,44]$ ) (Table 1). The wide range of phytic acid levels is related to methodology of phytic acid determination, plant variety and origin as well as how the plants have been cultivated [3]. Apart from influencing the phytic acid content, differences in growing conditions can also affect the iron content as well as the distribution of iron between phytate and ferritin in plants [13] and may thus significantly influence iron bioavailability of plant foods. 
Table 1. Iron [45] and phytic acid (PA) content [43] in common cereal foods.

\begin{tabular}{cccc}
\hline Food & $\begin{array}{c}\text { Phytic acid } \\
(\mathbf{g} / \mathbf{1 0 0} \mathbf{g})\end{array}$ & $\begin{array}{c}\text { Iron content } \\
(\mathbf{m g} / \mathbf{1 0 0} \mathbf{g})\end{array}$ & $\begin{array}{c}\mathbf{1}^{\mathbf{E}} \\
\text { molar ratio PA:Fe }^{\mathbf{2}}\end{array}$ \\
\hline Oatmeal & $0.80-1.03$ & 3.9 & $17-22$ \\
White bread & $0.28-1.00$ & 1.0 & $24-85$ \\
Whole grain bread & $0.43-1.05$ & 1.4 & $26-64$ \\
Rye bread (whole meal) & $0.03-0.41$ & 1.5 & $2-23$ \\
Rice & $0.06-2.20$ & 1.2 & $4-155$ \\
\hline
\end{tabular}

${ }^{1}$ The iron contents represent mean values and were not measured in the same products as the phytic acid;

${ }^{2}$ Rough estimates; calculated from a molar mass of phytic acid of $660 \mathrm{~g} / \mathrm{mol}$.

\section{Iron Intake and Requirements}

The iron contents of various cereal foods range from $\sim 0.3-4 \mathrm{mg} / 100 \mathrm{~g}$, with iron values in commonly consumed cereal foods ranging from $\sim 1-4 \mathrm{mg} / 100 \mathrm{~g}$ (Table 1). For comparison, red meat contains $\sim 0.2-2 \mathrm{mg}$ iron per $100 \mathrm{~g}$, but some meat products, e.g., liver, are very rich in iron, containing up to $31 \mathrm{mg}$ iron per $100 \mathrm{~g}$ [45]. In order to fulfil the physiological requirements, approximately 1-2 mg iron must be absorbed per day depending on gender and age, with menstruating women and children requiring more iron than other population groups [46]. In common western diets, an average of around $10 \mathrm{mg}$ ferric non-haem and $2 \mathrm{mg}$ haem iron is consumed daily [25]. These levels match the recommended intakes for boys and men, that according to the Nordic Nutrition Recommendations, are $11 \mathrm{mg} /$ day for boys aged 14-17, and $9 \mathrm{mg}$ iron/day for men aged 18 and older [47]. However, for women of the childbearing age and lactating women, the recommendation for iron intake is $15 \mathrm{mg} / \mathrm{day}$, with further recommendations on iron supplements during the second and third trimester for pregnant women [47], indicating that the iron requirements may not be met through the habitual diet.

\section{Non-Haem Iron Absorption in Humans}

Several factors determine the iron absorption from a meal: The amount and type of iron in the meal, the physiological mechanisms regulating iron absorption (uptake in intestinal cells and further transit) and the availability of the iron for uptake by the cellular transporters in the small intestine [48]. The iron status of the individual is another important determinant for iron absorption. Iron balance is maintained primarily by the iron-regulatory hormone hepcidin, which inhibits intestinal iron absorption and cellular iron release [25]. Hepcidin levels are upregulated by iron overload and inflammation, and downregulated by hypoxia and upon increased need for iron for erythropoiesis [25].

For the mechanism of absorption, haem iron is readily absorbed in the intestinal system by receptor-mediated endocytosis or direct haem transporters, although the detailed mechanisms are not fully elucidated [49].

More details are known regarding the mechanism for non-haem iron absorption. Non-haem iron is absorbed in the proximal part of the duodenum after reduction of $\mathrm{Fe}^{3+}$ (which is the more common oxidation state of iron in food) to $\mathrm{Fe}^{2+}$ by action of a ferrireductase, presumably duodenal cytochrome-b (Dcytb), present in the apical brush border of the intestinal wall $[25,49]$. A binding site for ascorbate on this enzyme underlines the role of ascorbic acid as an electron donor for $\mathrm{Fe}^{3+}$ 
reduction [30]. $\mathrm{Fe}^{2+}$ ions are then transported into the enterocyte using the divalent metal transporter-1 (DMT-1), which is also located in the apical brush border. This transport reaction is proton-driven, indicating that an acidic environment (optimal $\mathrm{pH}$ 5.5-5.8) is required for iron absorption, underlining that the primary site of iron absorption is just distal to the pylorus, where $\mathrm{pH}$ is still relatively low [25]. Expression of DMT-1 is induced in iron-deficient individuals [25]. Iron in the enterocytes can be retained or shuttled out of the cell, but the further fate of absorbed iron will not be considered in this review.

There is a surprising scarcity of data unravelling the details concerning the mechanism of cellular uptake of iron complexed to phytate and/or lower inositol phosphates (i.e., inositols with $\leq 5$ phosphates), but iron complexed with phytate is probably not directly bioavailable for entering the pathway for iron absorption described above. The currently available evidence is thus weak or non-existent, but a plausible scenario is that absorption of iron bound in iron phytate complexes into the enterocytes from the duodenum lumen can only occur after the iron has been released from the phytate, and reduced from the $\mathrm{Fe}^{3+}$ to the $\mathrm{Fe}^{2+}$ form. It remains to be elucidated, whether and how $\mathrm{Fe}^{3+}$ more loosely chelated to inositol phosphates is absorbed. Competition between ascorbic acid and phytate as iron chelators may play a role [3], as the ascorbic acid-iron complex is presumably available for absorption.

\section{Chemical Form of Iron Phytate Complexes in the Gastrointestinal System}

The chemical form of the phytate in the gut is an important parameter for the assessment of non-haem iron bioavailability in the gut. Phytate shows increasing chelating affinity, i.e., lower dissociation constant, from mono- to multivalent cations [3]. However, factors such as competing chelating agents should also be taken into consideration when evaluating the iron phytate interactions in the gut.

As previously mentioned, the $\mathrm{pK}_{\mathrm{a}}$ values of the phytate phosphates result in phytate being negatively charged at physiologically relevant $\mathrm{pH}$ values, i.e., $\mathrm{pH}$ values lower than $\sim 1$ are necessary for phytic acid to be in the fully protonated form. After a meal, $\mathrm{pH}$ in the stomach is typically $\sim 3-7$, decreasing gradually over a few hours to the fasting $\mathrm{pH} \sim 2$ [50-52]. Assuming that the $\mathrm{pK}_{\mathrm{a}}$ values are independent of iron binding, phytate will thus carry six negative charges in the gastric ventricle ( $\mathrm{pH}$ range $\sim 3-7$ ).

It has recently been experimentally confirmed that the iron phytate complex will be primarily in the associated monoferric form in the $\mathrm{pH}$ range above $\sim 4$, with $\mathrm{Fe}^{3+}$ existing as free ferric ions or ferric hydroxides at lower $\mathrm{pH}$ values [53]. The predominating forms between $\mathrm{pH} 3$ and 7 are tri-, di-, monoand non-protonated monoferric phytate with non-protonated monoferric phytate being the prevailing form at $\mathrm{pH}$ values exceeding $\sim 5.8$ [53] (Figure 1).

Studies on the sequestering ability of phytate have shown that the relative affinity of phytate towards different metal cations depends on $\mathrm{pH}$, meaning that for example at $\mathrm{pH} \sim 6-8, \mathrm{Fe}^{3+}$ is chelated more strongly than $\mathrm{Cr}^{3+}$ and $\mathrm{Al}^{3+}$ ions, whereas iron is the least strongly chelated of the three metal species at $\mathrm{pH}$ values below $\sim 6$ [53]. Furthermore, the concentration of phytate at which $50 \%$ of iron present in trace amounts is chelated has been found to range from $4.7 \times 10^{-6} \mathrm{M}$ to $1.1 \times 10^{-10} \mathrm{M}$ from pH 4.0-7.4 [53]. Hence, if, for example, $60 \mathrm{~g}$ oatmeal (containing, e.g., $0.9 \mathrm{~g}$ phytic acid/100 g, 
see Table 1) is consumed with milk resulting in a total volume of the gastric ventricle after intake of $\sim 0.5 \mathrm{~L}$, the potential concentration of phytate in the stomach is $\sim 1 \mathrm{mM}$, thus at least 1000 -fold higher than the concentration necessary to sequester $50 \%$ of the iron ions. Ismail-Beigi et al. [54] found that wheat bran binds $72 \%$ of iron $(0.5 \mathrm{mg} / \mathrm{L})$ in vitro at $\mathrm{pH} 6.5-6.8$ (duodenal $\mathrm{pH}$ range), which corroborates that most iron is associated with phytate in the $\mathrm{pH}$ conditions of the human gastrointestinal system.

Furthermore, it has been proposed that inositol triphosphate (myo-inositol phosphorylated on $\mathrm{C} 1$, $\mathrm{C} 2$ and $\mathrm{C} 3$ ) quantitatively chelates $\mathrm{Fe}^{3+}$ in a 1:1 ratio at physiologically relevant $\mathrm{pH}$ values (including acidic environments) [55]. Another study has shown that complexation of phytate with $\mathrm{Fe}^{3+}$ causes acidification, meaning that phytate is further deprotonated upon association with $\mathrm{Fe}^{3+}$ and that at $\mathrm{Fe}^{3+}$ :phytate ratios higher than $\sim 4$, intermolecular interactions will occur, forming a network of ferric phytates causing precipitation of aggregates [56].

As earlier mentioned, phytate in the plants naturally exists as mixed salts of several different mineral cations. It can therefore be speculated that under physiological conditions in the gastrointestinal system, the phytate molecule will still be associated with several different cations as well as the iron, although no exact information could be found on this matter.

\section{Degradation of Phytate in the Human Gastrointestinal System}

Very few studies have been conducted on the hydrolysis of phytate, notably iron phytate complexes and phytate globoids, in the human gastrointestinal system, including the hydrolysis of phytate in the stomach [57]. Early studies showed only limited degradation, i.e., dephosphorylation, of phytate in the human gastrointestinal system as measured by recovery of $\sim 40 \%-70 \%$ phytate in faeces $[58,59]$.

Human ileostomy studies conducted by Sandberg's group [60-62] showed that 95\% $\pm 10 \%$ of phytate initially present in the diet was recovered after passage of an extruded wheat bran diet through the stomach and small intestine with no detection of lower inositol phosphates, whereas $42 \% \pm 12 \%$ of the phytate was recovered in an unprocessed wheat bran diet and with detectable amounts of inositol penta-, tetra- and triphosphates in the ileostomy content [62]. They also found that the absorption of $\mathrm{Zn}, \mathrm{Mg}$ and $\mathrm{P}$ was significantly decreased from the extruded product, whereas absorption of $\mathrm{Ca}$ and $\mathrm{Fe}$ was at the same level for the two products, indicating that phytate needs to be dephosphorylated to a higher extent for Fe and Ca release to occur compared to $\mathrm{Zn}, \mathrm{Mg}$ and $\mathrm{P}$.

It was later shown that very low phytase enzyme activity (see Section 8 on phytases below) is present in the human small intestine [63], so degradation of phytate in the gastrointestinal system is most likely ascribable to the presence of dietary phytase enzyme (endogenous to wheat) [64], although it has later been suggested that after the initiation of phytate dephosphorylation by endogenous food phytases, intestinal phosphatase enzymes may play a role in continuing the dephosphorylation [57].

As iron is absorbed in the small intestine, phytate hydrolysis occurring after this point in the intestinal system is not relevant with regard to increasing iron absorption. Therefore, phytate hydrolysis in the large intestine is not considered in the present review.

In conclusion, natural degradation of phytate in the human gastrointestinal system is insufficient with regard to the release of absorbable iron from iron phytate complexes. One strategy that has been 
suggested to alleviate this problem is the use of exogenous phytase enzymes, catalysing the dephosphorylation of phytate, in food processing and during in vivo digestion.

\section{Phytases}

Phytases are a subgroup of phosphorolytic enzymes that are capable of initiating (and continuing) the hydrolysis of phosphate groups from phytate. Phytases are used widely in feed for non-ruminant animals [65] and are classified according to their catalytic mechanism (histidine acid phytases, $\beta$-propeller phytases, cysteine phytases and purple acid phytases), $\mathrm{pH}$ optima (acid or alkaline phytases) and site of phytate hydrolysis initiation (3-phytases, E.C. 3.1.3.8; 6-phytases, E.C.3.1.3.26 and 5-phytases, E.C.3.1.3.72) [66].

Most commercially available feed phytases are of fungal (Aspergillus niger) or bacterial (Escherichia coli) origin; they include both 3- and 6-phytase type histidine acid phytases and have a molecular weight of $\sim 45-50 \mathrm{kDa}, \mathrm{pH}$ optima range within $\sim 2.0-5.5$ and temperature optima at $\sim 50-60{ }^{\circ} \mathrm{C}$ [65]. Many others have reviewed the properties, reaction mechanisms and production of different phytases, see, e.g., [2,65-70].

The World Health Organization has recently evaluated the 3-phytase from Aspergillus niger for use in and with food for humans and found it safe for consumption with an acceptable daily intake "not specified" [71]. It remains to be seen whether other phytases that are used for animal feeds will be recognised as safe for human consumption.

On this note, a patent for an iron fortification nutritional blend containing phytase has recently been granted to DSM, corroborating the industrial potential and actuality of these enzymes for defying iron deficiency in humans [72].

\section{Degradation of Iron Phytate Complexes in the Gastrointestinal System}

\subsection{Activity of Phytases in the Gastrointestinal System}

The gastrointestinal system constitutes a hostile environment for most enzymes, particularly due to the low $\mathrm{pH}$ in the stomach and the presence of proteolytic enzymes, notably pepsin in the stomach and trypsin and chymotrypsin in the small intestine.

It has been shown that endogenous wheat phytases are mostly active in the gastric ventricle, where they retain $\sim 9 \%$ of their activity (compared to the activity in the feed of $43 \mathrm{mU} / \mathrm{mg}$ protein), whereas in the small intestine activity retention is only $\sim 2 \%$; in practice meaning that wheat phytase-catalysed phytate degradation takes place in the stomach only [73].

The enzyme inactivation is caused by proteolysis by pepsin in the pylorus and unfavourable $\mathrm{pH}$ conditions in the duodenal chyme ( $\mathrm{pH}$ 6.5-7), as wheat phytase has a pH optimum of 5.5 and 6.0 [40].

For comparison, A. niger phytase is expected to retain $50 \%-60 \%$ activity in the stomach [74] and has optimum activity at $\mathrm{pH} 2.0$ and 6.0 at $37^{\circ} \mathrm{C}$ with activity in the entire range from $\mathrm{pH} 1.0-7.5$ [75].

In one study, $A$. niger phytase has been found to continue phytate degradation in the duodenum [76]. Another study reported that $A$. niger phytase retained $95 \%$ activity after incubation at pH 3.5 with $5 \mathrm{mg}$ pepsin/mL compared to only $70 \%$ activity retention for the wheat phytase [77]. E. coli phytase has been found to exhibit an even higher stability in an acidic proteolytic (pepsin) 
environment compared to the $A$. niger phytase, whereas $A$. niger phytase has been reported to be more stable than $E$. coli phytase when incubated with trypsin at $\mathrm{pH} 7.5$ [68]. On a final stability note, fungal phytases generally have higher thermal stability than bacterial phytases [65].

\subsection{Role of Exogenous Phytases in Gastrointestinal Phytate Degradation}

Supplementation of exogenous $A$. niger phytase to a wheat-based meal can improve iron absorption compared to endogenous wheat phytases by degradation of phytate in the gastrointestinal system [75]. Unfortunately, data from human studies regarding the details and mechanism of degradation of phytate (notably iron phytate and phytate globoids) in the gastrointestinal system using exogenous phytases are not available. However, an in vivo study in pigs has shown that endogenous feed phytases as well as added $A$. niger phytase (1800 FTU/kg feed) can catalyse the hydrolysis of phytate. This hydrolysis seems to be dependent on the extent of phytate solubility in the stomach (which was $2 / 3$ ) [73], as higher dosage of exogenous phytases did not increase phytate degradation. This indicates that solubility rather than catalytic activity limited phytate degradation. However, degradation of phytate to lower inositol phosphates increases their solubility [73] and susceptibility towards further degradation and lowers their affinity for mineral chelation $[3,78]$.

Due to the $\mathrm{pH}$ increase, solubility of the inositol phosphates decreases as the food chyme is passed on to the duodenum, with lower inositol phosphates still exhibiting higher solubility than more phosphorylated inositols [3,73]. As the higher inositol phosphates have a higher tendency towards mineral chelation, the result is co-precipitation of mineral ions, e.g., $\mathrm{Fe}, \mathrm{Zn}$ and $\mathrm{Ca}$, thus making them unavailable for absorption [3]. On the other hand, the lower inositol phosphates, notably inositol di- and triphosphates, seem to keep the minerals in solution in the small intestine and potentially aid in the absorption of minerals in the small intestine [3].

Further hydrolysis in the duodenum is limited by the low solubility of the iron inositol phosphate complexes [73] as well as the acidic $\mathrm{pH}$ optima of most of the available microbial phytases that are under consideration for this application. Low substrate solubility in the small intestine is the main reason why the gastric ventricle is considered the primary target site for action of exogenous phytases for both phosphate (particularly relevant in animal nutrition) and iron release from iron phytate complexes.

\subsection{Extent of Phytate Degradation and Iron Absorption}

Having phytate partly dephosphorylated, the question is to which extent dephosphorylation is required to release iron for absorption. In an early study, lower inositol phosphates, notably inositol hexa- to tri-phosphates, were found to impair iron absorption proportionally to the degree of phosphorylation [79]. In a subsequent study conducted by the same group it was found that inositol hexa- and pentaphosphates inhibit iron absorption, whereas inositol tetra- and triphosphates alone do not inhibit iron absorption due to lower affinity for $\mathrm{Fe}^{3+}$ chelation [80]. However, the inositol tetra- and triphosphates were found to interact with higher inositol phosphates in inhibiting iron absorption and thus, it was concluded that at least four phosphates should be hydrolysed from phytate in order to significantly improve iron absorption from cereals and legumes. 
Quantitatively, $\mathrm{Yu}$ and co-workers found that, compared to inositol hexaphosphate, the inositol pentaphosphates had a chelating power of $\sim 70 \%-76 \%$, inositol tetraphosphates $\sim 35 \%$ and inositol triphosphates $\sim 30 \%$, whereas inositol di- and monophosphates exhibited no chelating power towards $\mathrm{Fe}^{3+}$ at $\mathrm{pH} 2.4$ [78]. The stoichiometry of the detected iron phytate complex under these conditions was $2: 1[78]$.

In order to significantly improve iron bioavailability, complete degradation of phytate is therefore recommended [12,57]. Complete phytate degradation, i.e., complete dephosphorylation, is expected to increase iron absorption five-fold or more [12] (up to 12-fold [34]), whereas a $\sim 90 \%$ degradation would cause only a two-fold increase in iron absorption [12]. Lower degrees of hydrolysis are not expected to be useful with regard to iron absorption, since the iron will still be bound to phytate or lower inositol phosphates, but if complete dephosphorylation of phytate cannot be achieved, it is advised to keep the molar phytate:iron ratio below $\sim 1: 1$, preferably below $\sim 0.4: 1$, in order to limit the phytate chelation of iron that renders the iron unavailable for absorption [34].

\section{Potential of Phytase-Mediated Iron Release from Plant Foods}

When assessing the potential of phytase-mediated iron release from plant foods in human studies, several issues need to be considered, e.g., iron status of the individuals in the study; dietary factors including, but not limited to, phytate content; how iron status can be assessed (which parameters are more suitable for evaluation and how informative in vitro studies can be conducted); where the phytate hydrolysis should take place (e.g., prior to ingestion or during digestion); to which extent the phytate should be dephosphorylated to significantly release iron; in which form released iron is present and the bioavailability of this iron form.

When considering in vivo phytase catalysis, a range of questions arises regarding where in the gastrointestinal system and to what extent the phytase is active, what the form of the substrate (soluble, insoluble/aggregated, dissociated or complexed with minerals, degree of protonation) is at the site of catalysis and the affinity of the phytase for this form of phytate. It has, for instance, been shown by Tang et al. [81] that if phytate is present as precipitated phytate salts (e.g., ferric phytate) at $\mathrm{pH}$, phytases from neither wheat Aspergillus ficuum nor Bacillus subtilis are able to catalyse the dephosphorylation of phytate. On the other hand, Bohn et al. [40] found that wheat phytase was active on phytate globoids at $\mathrm{pH} 6$, indicating that the natural form of the phytate is accessible for degradation.

When phytate is degraded ex vivo prior to ingestion of the food, the process can be monitored more easily and more reproducible and predictable results are likely to be obtained.

With regard to the released iron, whether it is released prior to or after consumption, it is relevant to know its chemical form and biological availability.

\subsection{Effect of Evaluation Parameters in in Vitro Studies}

Generally, three parameters are most often assessed when results from in vitro/ex vivo studies are reported:

1 Extent of phytate degradation and content of lower inositol phosphates;

2 Dialysability of iron; 
3 Cellular availability and/or uptake of iron.

Of these, the last is the pertinent health parameter and the question is therefore to what extent the cellular availability and uptake of iron is explained by the other parameters, which are usually easier to evaluate.

\subsubsection{Phytate Degradation}

Phytate degradation is one of the most reported parameters, and possibly the least relevant of the three. In assessing reported results on phytate degradation, it is important to consider the method of phytate determination as different methods will report different results. Two methods exploiting the interaction of ferric iron with inositol phosphates are used, either for precipitation of ferric phytate (originally developed by Heubner and Stadler [82]) or as interactions resulting in soluble complexes as is the case with Wade's reagent (ferric chloride and sulfosalicylic acid) [83]. These are relatively non-specific for phytate, as lower inositol phosphates are also able to participate in these interactions. Confirming this, Sandberg and co-workers concluded that the iron precipitation method was not suitable for evaluating phytate degradation [62]. Instead, various chromatographic separations can be performed to separate phytate from lower (i.e., less phosphorylated) inositol phosphates and thus give a better picture of the degree of dephosphorylation (e.g., [84]). Due to the significantly different outcome resulting from the use of different methods, some of the quantitative comparisons of the results obtained in different studies (regarding phytate degradation) are hampered by the influence of different methodologies. In particular, this influence hampers the complete understanding and comparisons with respect to the possible significance of inositols phosphorylated to different extents on the release and absorption of iron.

\subsubsection{Dialysability of Iron}

In vitro dialysability studies are useful in screening experiments when comparing iron absorption between different food items or meals, but a dialysis may exclude iron bound in large complexes that are bioavailable and on the other hand may include iron bound in smaller complexes (e.g., lower inositol phosphates and even phytate [85]) and yet are not bioavailable [86]. Argyri and co-workers found a good correlation between iron dialysability (particularly ferrous iron dialysability) and iron absorption in humans, indicating that ferrous iron dialysability can explain $\sim 75 \%$ of the variation in in vivo absorption studies (67\% explained by total dialyzable iron) [87]. Others report that dialysis studies usually, but not always, predict the right direction of the response (iron absorption) and that the magnitude of the response does not always correlate with what is found in human studies [88].

\subsubsection{Caco-2 Cellular Iron Uptake}

Even though there are no substitutes for in vivo studies, Caco-2 cell models provide an alternative to expensive and time-consuming human studies [89] and it has been demonstrated that Caco-2 cells models can correctly predict the influence on iron bioavailability response of all key iron absorption modifiers [88]. In vitro model systems with Caco-2 cells are normally implemented with a two-phased simulated digestion mimicking the conditions in the stomach and the small intestine [90]. Often these 
simulations are run with a $\mathrm{pH} \sim 2$ phase simulating the gastric ventricle and a $\mathrm{pH} \sim 7$ phase simulating the small intestine. This model, however, has a risk of overestimating the phytate degradation due to the very low $\mathrm{pH}$ value in the stomach simulation. Studies have shown that $\mathrm{pH}$ in the stomach after a meal is in the range of $\sim 3-7$, meaning that phytate complexes will be less soluble in vivo than in the in vitro model, demonstrated by the finding that $\sim 5 \%$ of phytate is soluble at $\mathrm{pH} 5.5$ in simulated wheat gruel digesta compared to $\sim 55 \%-70 \%$ at $\mathrm{pH} 2-4$ [91]. The $\mathrm{pH}$-dependence of solubility poses a potential bias of many in vitro studies, which should be kept in mind when evaluating results from these studies.

Iron uptake in Caco-2 cells can be measured either as incorporation of radiolabelled iron or as an increase in ferritin in the cell, both of which have shown good correlation with iron absorption in humans from some in vivo studies on the effect of different dietary factors, whereas for other studies, no correlation has been found $[88,90,92]$. With regard to the influence of polyphenols and phytate on iron uptake, it has been reported that the sensitivity of Caco-2 cells models is similar to what is observed in human studies [88].

When compared to the dialysis evaluation, cellular uptake provides a better estimate of in vivo absorption, as dialysis only evaluates passive diffusion of iron, whereas in cell models, active cellular iron absorption is also taken into consideration [85]. It is also possible that the total fraction of dialysable iron is not available for cellular absorption [85], indicated, e.g., by a lack of proportionality between iron dialysability and Caco-2 cellular uptake in a study by Sanz-Penella et al., where it was explained by inhibitory concentrations of inositol hexa- and pentaphosphates [93]. Lynch concludes that the Caco-2 cell model may not accurately reflect the magnitude of the effects that influence iron absorption [48] and it should also be kept in mind that Caco-2 cell studies are often conducted with one layer of cells, thus having a significantly lower surface area available for absorption compared to the in vivo intestinal system [93].

\subsection{Effect Evaluation Parameters in in Vivo Studies}

Iron bioavailability from foods is often evaluated by quantifying uptake of radio- or stable isotope labelled extrinsic iron that has been added to the food [89]. Otherwise, general iron status and iron absorption in in vivo studies can be evaluated using iron status indicators such as blood haemoglobin concentration, serum ferritin, transferrin receptors and/or iron concentration. Each of these has advantages and disadvantages: Haemoglobin concentration is a measure of anaemia and does not necessarily evaluate iron status, as iron deficiency and anaemia do not always occur concomitantly [94]. Also, normal haemoglobin ranges varies widely among individuals, making assessment of general iron deficiency difficult and they may also be affected by other factors such as malaria, malnutrition, age and pregnancy [95]. Serum ferritin has been shown to be a good indicator of body iron stores in healthy individuals, but is influenced by infections and acute or chronic inflammations [96]. Transferrin receptors are carrier proteins for transferrin and used as a marker of iron status. Transferrin receptors as an iron indicator has the advantage over serum ferritin that it is unaffected by inflammatory conditions [97]. Serum iron is linked to iron adequacy for development of red blood cells, but is not a good indicator of iron status due to diurnal and post-meal variations [94]. 


\subsection{Previous Studies on Phytases for Food Processing in Vitro and in Vivo}

\subsubsection{Studies Evaluating Efficacy of in Vivo Phytase Catalysis}

Some of the earliest studies assessing the potential of enzymatic phytate degradation in vivo in humans were conducted by Sandberg and co-workers, who already in 1988, in a meal-study over two four day periods, showed that addition of extra endogenous wheat phytase in the form of bran increased phytate degradation in vivo compared with addition of phytase-deactivated bran [64] (Table 2). The potential of exogenous phytases for improving iron bioavailability was demonstrated by this group by assessing iron absorption from wheat rolls containing added fungal phytase (Aspergillus niger phytase). The iron absorption increased $83 \%$ from $14.3 \%$ to $26.1 \%$ [75] (Table 2). A more recent study has also shown that addition of $A$. niger phytase to cereal porridge can increase iron absorption $23 \%-70 \%$ (with a better effect on iron as $\mathrm{FeSO}_{4}$ compared to NaFeEDTA) or up to $75 \%$ when added together with ascorbic acid [74] (Table 2). The study reported a total effect of ascorbic acid and phytase of $\sim 400 \%$ increase in iron absorption from NaFeEDTA compared with iron absorption from $\mathrm{FeSO}_{4}$ given without absorption enhancers [74] (Table 2). This is in line with the consensus that ascorbic acid is a non-haem iron absorption enhancer [25].

All studies designed to boost in vivo phytate degradation via addition of $A$. niger phytase to a meal (with the enzyme added just prior to the ingestion, e.g., drizzled on top of bread or mixed into porridge) have shown that the phytase can act in vivo and generate a positive effect on iron bioavailability (Table 2). To our knowledge, no studies have documented the effect of in vivo phytate hydrolysis in humans catalysed by phytases from other organisms, but as discussed below, other phytases have been shown in vitro to potentially exhibit effects similar to the $A$. niger phytase. Iron absorption in response to phytase addition in the reported in vivo studies have ranged from $2.4 \%$ to $26 \%$ and with iron intakes per meal ranging from $\sim 2.5$ to $8 \mathrm{mg}$. This increased iron absorption in effect results in absolute iron absorptions of up to $\sim 0.5-1 \mathrm{mg}$ per meal. Such an improvement infers that a cereal-based meal with phytase-enhanced iron absorption can produce a significant improvement with regard to the average requirements of $1-2 \mathrm{mg}$ iron/day. 
Table 2. Condensed results from in vivo phytase catalysis studies. Abbreviations:

CA: citric acid; AA: ascorbic acid; AN: Aspergillus niger; M: male; F: female; C: children;

ID: iron-deficient; NA: non-anaemic; $\mathrm{SF}$ : serum ferritin; $\mathrm{Hb}$ : haemoglobin;

CRP: C-reactive protein; TfR: transferrin receptor; w/wo: with/without.

\begin{tabular}{|c|c|c|c|c|c|c|}
\hline Treatment & $\begin{array}{c}\text { Study design and } \\
\text { duration } \\
\end{array}$ & $\begin{array}{c}\text { Iron } \\
\text { dosage }\end{array}$ & Test group & $\begin{array}{l}\text { Evaluation } \\
\text { parameter }\end{array}$ & Result & Reference \\
\hline $\begin{array}{l}\text { Active or inactivated } \\
\text { endogenous wheat bran } \\
\text { phytase }\end{array}$ & $\begin{array}{l}\text { Meal study } \\
2 \times 4 \text { day periods }\end{array}$ & $\mathrm{n} / \mathrm{a}$ & $\begin{array}{l}8 \mathrm{M}, 1 \mathrm{~F} \\
\text { ileostomy patients } \\
\text { (no information on } \\
\text { iron status) }\end{array}$ & $\begin{array}{l}\text { Phytate } \\
\text { degradation } \\
\text { (Fe absorption } \\
\text { not evaluated) }\end{array}$ & $\begin{array}{l}\uparrow \text { from } \sim 5 \% \text { with deactivated wheat } \\
\text { bran phytase to } \sim 60 \% \text { with active } \\
\text { wheat bran phytase }\end{array}$ & [64] \\
\hline $\begin{array}{l}\text { Active or inactivated } \\
\text { endogenous wheat } \\
\text { phytase or AN phytase }\end{array}$ & $\begin{array}{l}2 \text { separate meal } \\
\text { studies with wheat } \\
\text { rolls: (1) Active or } \\
\text { inactivated wheat } \\
\text { phytase; (2) Phytase- } \\
\text { inactivated wheat } \\
\text { bran w/wo AN } \\
\text { phytase }\end{array}$ & $\begin{array}{l}3.7 \mathrm{mg} \\
\text { labelled } \mathrm{Fe} \\
+0.4 \mathrm{mg} \\
\text { intrinsic } \\
\mathrm{Fe} / \mathrm{meal}\end{array}$ & $\begin{array}{l}9 \mathrm{M}, 11 \mathrm{~F} \text { split } \\
\text { into } 10 \text { in each } \\
\text { substudy } \\
\text { (no information on } \\
\text { iron status) }\end{array}$ & $\begin{array}{l}\mathrm{Fe} \text { absorption } \\
\text { (measurement of } \\
\text { radiolabelled } \\
{ }^{55} \mathrm{Fe} /{ }^{59} \mathrm{Fe} \text { in } \\
\text { blood samples) }\end{array}$ & $\begin{array}{l}\text { (1) No difference; }(2) \uparrow 83 \% \text { from } \\
14.3 \% \pm 2.6 \% \text { to } 26.1 \% \pm 3.8 \% \\
\text { with AN phytase }\end{array}$ & [75] \\
\hline $\begin{array}{l}\text { Maize porridge taken } \\
\text { with different } \\
\text { micronutrient powders } \\
\text { containing Fe } \\
\text { (as } \mathrm{NaFeEDTA} \text { or } \mathrm{FeSO}_{4} \text { ) with AN } \\
\text { phytase, AA, } \\
\text { L- } \alpha \text {-glycerophospho- } \\
\text { choline and/or } \mathrm{Ca}\end{array}$ & $\begin{array}{l}\text { Meal study } \\
\text { Crossover design } \\
\text { ( } 2 \text { days })\end{array}$ & $\begin{array}{l}3 \mathrm{mg} \\
\mathrm{Fe} / \mathrm{meal}\end{array}$ & $\begin{array}{l}101 \mathrm{~F} \text { ( } 21 \mathrm{ID}, \\
1 \mathrm{ID} \text { anaemic) } \\
\text { allocated to } \\
6 \text { separate iron } \\
\text { absorption studies } \\
(n=16-18 \text { in } \\
\text { each substudy) }\end{array}$ & $\begin{array}{l}\text { Fe absorption } \\
\text { (stable isotope } \\
\text { labelled }{ }^{57} \mathrm{Fe}{ }^{58} \mathrm{Fe} \\
\text { measurement in } \\
\text { erythrocytes } \\
14 \text { days later) }\end{array}$ & $\begin{array}{l}\text { Phytase: } \uparrow 23 \%-75 \% \text { from } \\
2.4 \%-5.0 \% \text { to } 4.1 \%-7.4 \% \text {. Highest } \\
\text { effect of phytase was observed in } \\
\text { combination with ascorbic acid, } \\
\text { where total increase as result of } \\
\text { phytase, ascorbic acid, and } \\
\text { NaFeEDTA resulted in } 400 \% \\
\text { absorption increase compared to } \\
\text { iron absorption from FeSO } 4 \\
\text { (1.5\% to } 7.4 \%) \text {. No significant } \\
\text { effect of other single factors }\end{array}$ & [74] \\
\hline $\begin{array}{l}\text { High-phytate porridge } \\
\text { taken with } \\
\text { micronutrient powder } \\
\text { containing } \mathrm{Zn}, \mathrm{Fe} \text { as } \\
\text { NaFeEDTA, AA and } \\
\text { AN phytase }\end{array}$ & $\begin{array}{l}\text { Diet study } \\
\text { (5 days/week for } \\
23 \text { weeks) } \\
\text { Double-blind } \\
\text { controlled study } \\
\text { Control: No Fe } \\
\text { supplement }\end{array}$ & $2.5 \mathrm{mg}$ & $\begin{array}{l}200 \mathrm{C} \\
\text { (low iron status) }\end{array}$ & $\begin{array}{l}\text { Fe status } \\
\text { (SF, Hb, CRP, } \\
\text { TfR content in } \\
\text { blood samples) }\end{array}$ & $\begin{array}{l}\text { Occurrence of Fe deficiency } \downarrow 75 \% \\
\text { ( } \downarrow 35 \% \text { in control group) } \\
\text { Body Fe } \uparrow 100 \%(\uparrow 40 \% \text { in control) } \\
\text { Fe absorption } \sim 7 \%-8 \%\end{array}$ & [98] \\
\hline $\begin{array}{l}\text { Fe-rich bread w/wo } \\
\text { phytase supplement } \\
\text { compared with } \\
\mathrm{FeSO}_{4} \text { supplement }\end{array}$ & Meal study & $\begin{array}{l}5-8 \mathrm{mg} \\
\mathrm{Fe} / \mathrm{meal}\end{array}$ & $\begin{array}{l}24 \mathrm{~F} \text { (borderline } \\
\text { anaemic) allocated to } \\
5 \text { test meals }\end{array}$ & $\begin{array}{l}\text { Fe status (serum } \\
\text { iron measured } \\
180 \text { and } 210 \text { min } \\
\text { after ingestion) }\end{array}$ & $\begin{array}{l}\text { Serum } \mathrm{Fe} \downarrow \text { in all groups at } 180 \text { and } \\
210 \text { min after intake except for the } \\
\text { positive control group given } \\
\mathrm{FeSO}_{4} \text { supplement. } \\
\text { Decrease in serum } \mathrm{Fe} \text { was largest in } \\
\text { the order of iron-rich bread }> \\
\text { control bread > iron-rich bread with } \\
0.010 \%(\mathrm{w} / \mathrm{w}) \text { phytase }>\text { iron-rich } \\
\text { bread with } 0.015 \%(\mathrm{w} / \mathrm{w}) \text { phytase }\end{array}$ & [99] \\
\hline
\end{tabular}


One research group observed a decline in serum iron after the study subjects had ingested the iron-rich meals [99]. Such a decline was also observed in a study conducted by Conway et al. [100], where the serum iron decline correlated with high amounts of phytate in the ingested meal. However, phytase diminished the serum iron decline compared to the control meal in the study by Bokhari et al. [99], indicating that high phytate intake could explain the decrease in serum iron levels, although in this latter study, the phytate content was unfortunately not reported. One study did not include a control group that received the meal with iron supplement, but without added phytase (although they did have a control group receiving a meal without any iron supplement), making it difficult to single out the added effect of the phytase on the iron absorption [98].

The available studies are obviously quite different with regard to design of study, target group, compositions of the meals or whole diets, especially with regard to the content of phytase and phytate:iron ratio, making any firm conclusions difficult. However, overall, the available data suggest that $A$. niger phytase may have the potential to improve in vivo iron absorption in humans.

\subsubsection{Studies Evaluating Efficacy of ex Vivo Phytase Catalysis on in Vivo Parameters}

Effect of phytase-mediated pretreatment of cereal-based foods has been documented as increases in in vivo iron absorption from $78 \%$ up to as much as $1066 \%$ in single meal studies $[12,101]$ (Table 3 ). However, a four-month intervention study with 41 women did not show an effect of phytase pretreatment [5] (Table 3). This was probably due to the low degree of phytate dephosphorylation $(\sim 22 \%)$ achieved with the enzyme treatment in this study, which was not enough to release iron from the phytate complexes (InsP5+6:Fe ratio was $\sim 0.6$ in the phytase-treated bread).

\subsubsection{Studies Evaluating Efficacy of ex Vivo Phytase Catalysis on in Vitro Parameters}

In vitro studies have shown that $A$. niger phytase has the potential to degrade phytate and thereby improve potential for iron absorption during in vitro digestion or as a pretreatment step for foods prior to ingestion (Table 4). One study found phytate degradation in bread with $A$. niger phytase to be up to $97 \%$, resulting in an increased cellular iron uptake by Caco-2 cells of $\sim 150 \%$ [102]. Similar results were obtained by Sanz-Penella et al. [93] ( 97\% InsP5+6 degradation, 92\% increase in iron uptake by Caco-2 cells) (Table 4).

Whereas reasonable correlation was seen between Caco-2 cell iron uptake and phytate degradation, the correlation between phytate degradation and dialysability is unclear, see e.g., Sanz-Penella et al. [103] and Akhter et al. [104], who find very different correlations between phytate degradation and iron dialysability (Table 4). This indicates that inositol phosphates (and especially lower inositol phosphates) can be dialysed, but are not available for cell uptake. The finding that iron uptake by Caco-2 cells only increase after extensive phytate degradation, i.e., in the order of $>90 \%$ degradation, also underlines that phytate degradation needs to be virtually complete and phytate:iron ratios should be low for iron absorption to increase [34,57]. One group has also shown potential of other microbial phytases (E. coli, A. fumigatus) for phytate degradation [21] (Table 4). 
Table 3. Condensed results from studies employing ex vivo phytase catalysis evaluated on in vivo parameters. Abbreviations: CA: citric acid; AN: Aspergillus niger; M: male; F: female; C: children; ID: iron deficient; NA: non-anaemic; SF: serum ferritin; InsP6: phytate; InsP3: myo-inositol triphosphate.

\begin{tabular}{|c|c|c|c|c|c|c|}
\hline Treatment & $\begin{array}{l}\text { Study design } \\
\text { and duration }\end{array}$ & $\begin{array}{l}\text { Iron } \\
\text { dosage }\end{array}$ & Test group & $\begin{array}{l}\text { Evaluation } \\
\text { parameter }\end{array}$ & Result & Reference \\
\hline $\begin{array}{l}\text { AN phytase addition } \\
\text { to cereal porridges } \\
\text { during manufacturing }\end{array}$ & Meal study & $\begin{array}{l}2.5 \mathrm{mg} \\
\mathrm{Fe} / \mathrm{meal}\end{array}$ & $\begin{array}{l}34 \mathrm{M}(1 \mathrm{ID}), \\
44 \mathrm{~F}(13 \mathrm{ID}), \\
\text { all NA }\end{array}$ & $\begin{array}{l}\text { Fe absorption } \\
\text { (measurement of } \\
\text { radiolabel-led } \\
{ }^{55} \mathrm{Fe} /{ }^{59} \mathrm{Fe} \text { in } \\
\text { blood samples) }\end{array}$ & $\begin{array}{l}\uparrow 209 \%-1066 \% \text { from } 0.3 \% \text { to } \\
2.4 \% \rightarrow 2.8 \%-11.5 \%\end{array}$ & [105] \\
\hline $\begin{array}{l}\text { AN phytase added } \\
\text { during making of } \\
\text { fibre-rich wheat bread }\end{array}$ & $\begin{array}{l}\text { Intervention } \\
\text { study; } 4 \text { months }\end{array}$ & $\begin{array}{l}6 \mathrm{mg} \\
\mathrm{Fe} / \mathrm{meal}, \\
14 \mathrm{mg} / \text { day }\end{array}$ & $\begin{array}{l}41 \text { iron- } \\
\text { sufficient } \mathrm{F}\end{array}$ & $\begin{array}{l}\text { Fe absorption } \\
\text { in vivo (SF) } \\
\text { InsP3-6 content } \\
\text { in bread }\end{array}$ & $\begin{array}{l}\text { No effect on SF by phytase } \\
\text { treatment; InsP5+6 contents } \\
\downarrow 17 \% \text {; InsP3-6 content } \downarrow 22 \%\end{array}$ & {$[5]$} \\
\hline $\begin{array}{l}\mathrm{CA} \text { and AN phytase } \\
\text { addition to oat } \\
\text { beverage as } \\
\text { pretreatment }\end{array}$ & $\begin{array}{l}\text { Meal study, } \\
4 \text { days }\end{array}$ & $\begin{array}{l}1.3 \mathrm{mg} \\
\mathrm{Fe} / \mathrm{meal}\end{array}$ & $\begin{array}{l}23 \mathrm{M}, 22 \mathrm{~F} \\
\text { (non-ID) }\end{array}$ & $\begin{array}{l}\text { Fe absorption } \\
\text { in vivo (radio- } \\
\text { labelled }{ }^{55} \mathrm{Fe} /{ }^{59} \mathrm{Fe} \\
\text { count in whole } \\
\text { body and } \\
\text { eryth-rocytes); } \\
\text { InsP3-6 content in } \\
\text { oat beverage }\end{array}$ & $\begin{array}{l}\text { CA: } \uparrow 54 \% \text { (from } 3.9 \% \text { to } 6.0 \% \text { ) } \\
\text { Phytase added with CA further } \\
\text { increased iron absorption by } 78 \% \\
(6.0 \% \rightarrow 10.7 \%) \text {; } \\
\text { Phytase reduced InsP3-6 to } \\
\text { undetectable amounts } \\
\text { (<1 mg/portion), phytate-P } \downarrow 83 \%\end{array}$ & [101] \\
\hline
\end{tabular}

Table 4. Condensed results from studies employing ex vivo phytase catalysis evaluated on in vitro parameters. Abbreviations: CA: citric acid; AA: ascorbic acid; AN: Aspergillus niger; InsP: myo-inositol phosphate; InsP6: phytate; InsP5: myo-inositol pentaphosphate; InsP3: $m y o$-inositol triphosphate; w/wo: with/without.

\begin{tabular}{|c|c|c|c|}
\hline Treatment & Evaluation parameter & Result & Reference \\
\hline $\begin{array}{l}\text { Addition of AN, } \\
\text { A. fumigatus or E. coli } \\
\text { phytase w/wo CA and AA to } \\
\text { whole-wheat bread dough }\end{array}$ & $\begin{array}{l}\text { Phytate }^{1} \text { degradation } \\
\text { Fe dialysability from bread }\end{array}$ & $\begin{array}{l}C A \text { : Phytate degradation } \uparrow \text { from } 42 \% \text { in control to } 69 \% \text {; } \\
\text { Fe dialysability } \uparrow 12 \text {-fold } \\
\text { AN phytase alone: Phytate degradation } 57 \% \text {, no significant effect } \\
\text { on dialysability } \\
\text { Microbial phytases }+C A \text { : } \\
A N \text { : Phytate degradation } 74 \%-85 \% \text { (dose-dependent); } \\
\text { Fe dialysability } \uparrow 15 \text {-fold. } \\
\text { E. coli: Phytate degradation } 63 \%-76 \% \text { (dose-dependent); } \\
\text { Fe dialysability not assessed } \\
\text { A. fumigatus: Phytate degradation } 83 \%-85 \% \text { (dose-dependent); } \\
\text { Fe dialysability not assessed } \\
\text { AN phytase }+C A+A A \text { : Fe dialysability } \uparrow 24 \text {-fold compared } \\
\text { to control }\end{array}$ & [21] \\
\hline $\begin{array}{l}\text { AN phytase addition during } \\
\text { making of different bread }\end{array}$ & Phytate ${ }^{1}$ degradation & $\begin{array}{l}\text { Phytate degradation } \uparrow 12 \%-57 \% \text { compared to control depending on } \\
\text { bread type, total phytate degradation with phytase: } 49 \%-90 \%\end{array}$ & [106] \\
\hline
\end{tabular}


Table 4. Cont.

\begin{tabular}{|c|c|c|c|}
\hline $\begin{array}{l}\text { High-phytase producing } \\
\text { yeast strains addition during } \\
\text { in vitro digestion of } \\
\text { wheat gruel }\end{array}$ & Phytate degradation & $\leq 59 \%$ & [91] \\
\hline $\begin{array}{l}\text { Bifidobacteria cell } \\
\text { suspensions or AN phytase } \\
\text { addition during } \\
\text { wheat bread making }\end{array}$ & InsP3-6 content in bread & $\begin{array}{l}\text { Phytase: each InsP } \downarrow 67 \%-100 \% \text { (mean } \pm \text { standard deviation } \\
91 \% \pm 10 \% \text { ) compared to control; } \\
\text { Bifidobacteria: each } \downarrow-8 \%-67 \%(19 \% \pm 27 \% \text { ) compared } \\
\text { to control }\end{array}$ & [107] \\
\hline $\begin{array}{l}\text { Highly phytase-producing } \\
\text { yeasts (experimental strains), } \\
\text { S. cerevisiae or } \text { A. ficuum } \\
\text { phytase addition to togwa } \\
\text { prior to ingestion }\end{array}$ & $\begin{array}{l}\text { Phytate degradation after } \\
48 \mathrm{~h} \text { fermentation }\end{array}$ & $\begin{array}{l}\text { S. cerevisiae: } 85 \% \\
\text { A. ficuum phytase: } 89 \% \\
\text { Experimental strains: } 95 \% \\
\text { Control: } 51 \%\end{array}$ & [108] \\
\hline $\begin{array}{l}\text { Activating endogenous } \\
\text { phytase in fortified and } \\
\text { non-fortified } \\
\text { flour/oilseed mixtures }\end{array}$ & Fe dialysability & $\begin{array}{l}\text { Wheat } / \text { soy: } \uparrow 43 \%-162 \% \text { (non-fortified); } \uparrow 40 \%-168 \% \text { (fortified); } \\
\text { Wheat/groundnut: } \uparrow 83 \%-192 \% \text { (non-fortified); } \\
97 \%-240 \% \text { (fortified) } \\
\text { Dialysable Fe in controls: } 1.3 \%-9.7 \%\end{array}$ & [109] \\
\hline $\begin{array}{l}\text { AN phytase addition during } \\
\text { in vitro digestion of bread }\end{array}$ & $\begin{array}{l}\text { Phytate degradation } \\
\text { Fe bioavailability in } \\
\text { Caco-2 cell model }\end{array}$ & $\begin{array}{l}\text { Phytate degradation } 89 \%-97 \% \\
\text { Cellular uptake of } \mathrm{Fe} \uparrow 152 \%-156 \%\end{array}$ & [102] \\
\hline $\begin{array}{l}\text { Fungal phytase or phytase- } \\
\text { producing bifidobacteria } \\
\text { addition during whole wheat } \\
\text { bread- or whole wheat } \\
\text { sourbread-making }\end{array}$ & $\begin{array}{l}\text { InsP5 + InsP6 degradation } \\
\text { Fe dialysability } \\
\text { Ferritin formation in } \\
\text { Caco-2 cells }\end{array}$ & $\begin{array}{l}\text { Whole wheat bread: } \\
\text { Fungal phytase: InsP5+6 degradation } \sim 97 \% \text {; dialysable } \mathrm{Fe} \uparrow 17 \% \text {, } \\
\text { dialysability } \downarrow 9 \% \text {; Caco-2 cell uptake } \uparrow 92 \% \\
\text { Bifidobacteria: InsP5+6 degradation } \sim 76 \% \text {; dialysable Fe } \uparrow 127 \% \text {, } \\
\text { dialysability } \uparrow 118 \% \text {; Caco-2 cell uptake } \uparrow 33 \% \text { (not significant) } \\
\text { Whole wheat sourbread: } \\
\text { Fungal phytase: InsP5+6 degradation } \sim 68 \% \text {; dialysable Fe } \uparrow 45 \% \text {, } \\
\text { dialysability } \uparrow 82 \% \text {; Caco-2 cell uptake } \uparrow 67 \% \text { (not significant) } \\
\text { Bifidobacteria: InsP5+6 degradation of } \sim 58 \%-70 \% \text {; dialysable Fe } \\
\uparrow 283 \%-456 \% \text {; dialysability } \uparrow 236 \%-391 \% \text {; Caco-2 cell uptake } \uparrow \\
0 \%-25 \% \text { (not significant) }\end{array}$ & [93] \\
\hline $\begin{array}{l}\text { A. oryzae phytase or } \\
\text { phytase-producing } \\
\text { bifidobacteria addition } \\
\text { during pretreatment of } \\
\text { infant cereals }\end{array}$ & $\begin{array}{l}\text { Phytate degradation } \\
\text { Fe dialysability }\end{array}$ & $\begin{array}{l}\text { A. oryzae phytase: } \\
\text { InsP6 } \downarrow 45 \%-67 \% \text { compared to control; InsP3-6 (total) } \\
\downarrow 25 \%-28 \% \text {; no change in Fe dialysability } \\
\text { Bifidobacteria: } \\
\text { InsP6 } \downarrow 75 \%-87 \% \text { compared to control; InsP3-6 (total) } \\
\downarrow 23 \%-63 \% \text {; no change in Fe dialysability }\end{array}$ & [103] \\
\hline $\begin{array}{l}\text { Exogenous wheat phytase } \\
\text { addition to wheat flour }\end{array}$ & $\begin{array}{l}\text { Phytate }{ }^{1} \text { degradation } \\
\text { Fe dialysability }\end{array}$ & $\begin{array}{l}\text { Phytate } \downarrow 35 \%-69 \% \\
\text { Fe dialysability } \uparrow 11 \%-52 \% \text { (from } 12 \% \text { to } 16 \% \text { to } 15 \%-25 \% \text { ) }\end{array}$ & [104] \\
\hline
\end{tabular}

${ }^{1}$ The term phytate has here been used to cover the higher inositol phosphates (as determined by Wade reagent or precipitation).

\section{Other Options for Enhancing Iron Absorption}

Other options for enhancing iron bioavailability from meals and/or whole diets have been reviewed extensively elsewhere (e.g., $[3,34,110]$ ) and includes the pretreatment of grains, e.g., soaking, malting 
and germination, as well as addition of organic acids, in particular ascorbic acid and citric acid, and various other complexing agents in order to minimise the inhibitory effect of phytate on iron absorption.

Clearly, some of the classical pretreatments such as soaking, malting and germination in fact serve to activate the endogenous cereal phytases, and in turn become phytase-mediated approaches.

Several approaches involving genetically modified crops, either with low phytate content or higher phytase activity, have also been considered [2], but these strategies have not yet gained ground.

Finally, direct fortification of foods and separate iron supplementation are of course still potential solutions to improve the iron status of vulnerable populations. As already discussed above, iron supplementation may work in combination with phytase-mediated degradation of phytate for improving iron absorption from phytate-rich meals.

\section{Conclusions}

Several studies indicate that microbial phytase ingested with a phytate-rich meal (with the phytase added to the food) or added as a pretreatment aid has potential for increasing iron absorption from single foods. The action mechanism is enzymatic phytate degradation, which — if virtually completewill result in release of chelated iron. It seems favourable to include citric and/or ascorbic acid in meals as these have been shown convincingly to act synergistically with the phytases in increasing iron absorption. The improved iron absorption potentially improves iron status in particularly iron-deficient individuals.

To our knowledge, only the A. niger phytase enzyme has been used in in vivo studies. It is therefore tempting to conclude that this particular enzyme is particularly effective in improving iron absorption via phytase degradation, but in vitro studies have suggested that other phytases can also effectively catalyse the degradation of phytate under physiologically relevant conditions. Fungal phytases have higher thermal stability than bacterial phytases, but the currently available data suggests that bacterial phytases, e.g., E. coli phytase, may also have potential due to an apparently higher proteolytic resistance against pepsin compared with the $A$. niger phytase, which in turn is more stable than the wheat phytase. Options for improving phytase stability in the gut should be investigated, including genetic engineering and/or formulation approaches. There are no substitutes for in vivo studies, but Caco-2 cell uptake studies have given good pre-clinical results and may provide a means to better unravel the detailed mechanisms of cellular iron receptor activation, compare iron bioavailability from different foods as well as deduce any correlations between phytase action rates for degradation of phytate, iron release, and cellular absorption rates. In any case, to improve our quantitative understanding the research must emphasise analysis and reporting of remaining inositol phosphate contents as well as phytate:iron ratios in the final digesta/pretreated food, since these parameters are crucial for determining iron absorption in vivo.

Further research on the exact chemical form of iron and phytate in the stomach and especially the possibility of cellular uptake from iron loosely chelated to lower inositol phosphates is needed in order to elucidate further the potential and mechanism of phytase-mediated iron release and absorption in the human body. In relation to this, a better understanding of the affinity of phytases towards soluble and insoluble iron phytate complexes present in phytate globoids is warranted. A deeper understanding of the significance of phytase dosage, kinetics (i.e., rates of dephosphorylation), and stability under 
gastrointestinal conditions would aid in identifying key focus points with regard to design of intelligent solutions for in vivo phytase catalysis. These issues are crucial for defining the efficacy of phytase-mediated iron release, as the time window for in vivo catalysis will be limited by both enzyme stability and gastrointestinal transit times. With more knowledge on these issues, engineering of better dietary solutions for improved iron absorption from cereal and other plant foods would be possible.

\section{Conflict of Interest}

The authors declare no conflict of interest.

\section{References}

1. World Health Organization. Worldwide Prevalence of Anaemia 1993-2005; WHO Press: Geneva, Switzerland, 2008.

2. Bohn, L.; Meyer, A.S.; Rasmussen, S.K. Phytate: Impact on environment and human nutrition. A challenge for molecular breeding. J. Zhejiang Univ. Sci. B 2008, 9, 165-191.

3. Schlemmer, U.; Frølich, W.; Prieto, R.M.; Grases, F. Phytate in foods and significance for humans: Food sources, intake, processing, bioavailability, protective role and analysis. Mol. Nutr. Food Res. 2009, 53, S330-S375.

4. Hunt, J.R. Bioavailability of iron, zinc, and other trace minerals from vegetarian diets. Am. J. Clin. Nutr. 2003, 78, 633S-639S.

5. Kristensen, M.B.; Tetens, I.; Jørgensen, A.B.; Thomsen, A.D.; Milman, N.; Hels, O.; Sandström, B.; Hansen, M. A decrease in iron status in young healthy women after long-term daily consumption of the recommended intake of fibre-rich wheat bread. Eur. J. Nutr. 2005, 44, 334-340.

6. Minihane, A.M.; Rimbach, G. Iron absorption and the iron binding and anti-oxidant properties of phytic acid. Int. J. Food Sci. Technol. 2002, 37, 741-748.

7. Hurrell, R.; Egli, I. Iron bioavailability and dietary reference values. Am. J. Clin. Nutr. 2010, 91, 1461S-1467S.

8. Hunt, J.R.; Roughead, Z.K. Nonheme-iron absorption, fecal ferritin excretion, and blood indexes of iron status in women consuming controlled lactoovovegetarian diets for 8 wk. Am. J. Clin. Nutr. 1999, 69, 944-952.

9. Monsen, E.R. Ascorbic Acid: An Enhancing Factor in Iron Absorption. In Nutritional Bioavailability of Iron; American Chemical Society: Washington, DC, USA, 1982; pp. 85-95.

10. Cook, J.D. Adaptation in iron metabolism. Am. J. Clin. Nutr. 1990, 51, 301-308.

11. Monsen, E.R. Iron nutrition and absorption: Dietary factors which impact iron bioavailability. J. Am. Diet. Assoc. 1988, 88, 786-790.

12. Hurrell, R.F. Influence of vegetable protein sources on trace element and mineral bioavailability. J. Nutr. 2003, 133, 2973S-2977S.

13. Theil, E.C.; Briat, J.-F. Plant Ferritin and Non-Heme Iron Nutrition in Humans; International Food Policy Research Institute and International Center for Tropical Agriculture: Washington, DC, USA, 2004.

14. May, L.; Morris, E.R.; Ellis, R. Chemical identity of iron in wheat by Mössbauer spectroscopy. J. Agric. Food Chem. 1980, 28, 1004-1006. 
15. Morris, E.R.; Ellis, R. Isolation of monoferric phytate from wheat bran and its biological value as an iron source to the rat. J. Nutr. 1976, 106, 753-760.

16. Grusak, M.A.; Pearson, J.N.; Marentes, E. The physiology of micronutrient homeostasis in field crops. Field Crop. Res. 1999, 60, 41-56.

17. Harrison, P.M.; Arosio, P. The ferritins: Molecular properties, iron storage function and cellular regulation. Biochim. Biophys. Acta Bioenerg. 1996, 1275, 161-203.

18. Theil, E.C.; Chen, H.; Miranda, C.; Janser, H.; Elsenhans, B.; Núñes, M.T.; Pizarro, F.; Schümann, K. Absorption of iron from ferritin is independent of heme iron and ferrous salts in women and rat intestinal segments. J. Nutr. 2012, 142, 478-483.

19. Kalgaonkar, S.; Lönnerdal, B. Receptor-mediated uptake of ferritin-bound iron by human intestinal Caco-2 cells. J. Nutr. Biochem. 2009, 20, 304-311.

20. Reddy, M.B.; Hurrell, R.F.; Cook, J.D. Estimation of nonheme-iron bioavailability from meal composition. Am. J. Clin. Nutr. 2000, 71, 937-943.

21. Porres, J.M.; Etcheverry, P.; Miller, D.D.; Lei, X.G. Phytase and citric acid supplementation in whole-wheat bread improves phytate-phosphorus release and iron dialyzability. J. Food Sci. 2001, 66, 614-619.

22. Tetens, I.; Bendtsen, K.M.; Henriksen, M.; Ersbøll, A.K.; Milman, N. The impact of a meatversus a vegetable-based diet on iron status in women of childbearing age with small iron stores. Eur. J. Nutr. 2007, 46, 439-445.

23. García-Casal, M.N.; Layrisse, M.; Solano, L.; Barón, M.A.; Arguello, F.; Llovera, D.; Ramírez, J.; Leets, I.; Tropper, E. Vitamin A and beta-carotene can improve nonheme iron absorption from rice, wheat and corn by humans. J. Nutr. 1998, 128, 646-650.

24. Layrisse, M.; García-Casal, M.N.; Solano, L.; Barón, M.A.; Arguello, F.; Llovera, D.; Ramírez, J.; Leets, I.; Tropper, E. New property of vitamin A and B-carotene on human iron absorption: Effect on phytate and polyphenols as inhibitors of iron absorption. Arch. Latinoam. Nutr. 2000, 50, 243-248.

25. Andrews, N.C. Iron Metabolism. In Principles of Molecular Medicine; Runge, M.S., Patterson, C., Eds.; Humana Press: New York, NY, USA, 2006; pp. 848-853.

26. Petry, N.; Egli, I.; Zeder, C.; Walczyk, T.; Hurrell, R. Polyphenols and phytic acid contribute to the low iron bioavailability from common beans in young women. J. Nutr. 2010, 140, 1977-1982.

27. Janet, R. Hunt algorithms for iron and zinc bioavailability: Are they accurate? Int. J. Vitam. Nutr. Res. 2010, 80, 257-262.

28. Fairweather-Tait, S.J.; Collings, R. Estimating the bioavailability factors needed for setting dietary reference values. Int. J. Vitam. Nutr. Res. 2010, 80, 249-256.

29. Hambidge, K.M. Micronutrient bioavailability: Dietary reference intakes and a future perspective. Am. J. Clin. Nutr. 2010, 91, 1430S-1432S.

30. McKie, A.T. The role of Dcytb in iron metabolism: an update. Biochem. Soc. Trans. 2008, 36, 1239-1241.

31. Hurrell, R.F. Fortification: Overcoming technical and practical barriers. J. Nutr. 2002, 132, 806S-812S.

32. Hallberg, L. Wheat fiber, phytates and iron absorption. Scand. J. Gastroenterol. Suppl. 1987, 22, 73-79. 
33. Sandberg, A.-S. Bioavailability of minerals in legumes. Br. J. Nutr. 2002, 88, S281-S285.

34. Hurrell, R.F. Phytic acid degradation as a means of improving iron absorption. Int. J. Vitam. Nutr. Res. 2004, 74, 445-452.

35. Jin, F.; Frohman, C.; Thannhauser, T.W.; Welch, R.M.; Glahn, R.P. Effects of ascorbic acid, phytic acid and tannic acid on iron bioavailability from reconstituted ferritin measured by an in vitro digestion-Caco-2 cell model. Br. J. Nutr. 2009, 101, 972-981.

36. Lönnerdal, B. The importance and bioavailability of phytoferritin-bound iron in cereals and legume foods. Int. J. Vitam. Nutr. Res. 2007, 77, 152-157.

37. Loewus, F.A. Biosynthesis of Phytate in Food Grains and Seeds. In Food Phytates; Reddy, N.R., Sathe, S.K., Eds.; CRC Press: Boca Raton, FL, USA, 2001.

38. Raboy, V. Progress in breeding low phytate crops. J. Nutr. 2002, 132, 503S-505S.

39. Lott, J.N.A. Accumulation of Seed Reserves of Phosphorous and Other Minerals. In Seed Physiology; Academic Press Australia: Toowong, Australia, 1984; pp. 139-166.

40. Bohn, L.; Josefsen, L.; Meyer, A.S.; Rasmussen, S.K. Quantitative analysis of phytate globoids isolated from wheat bran and characterization of their sequential dephosphorylation by wheat phytase. J. Agric. Food Chem. 2007, 55, 7547-7552.

41. Borg, S.; Brinch-Pedersen, H.; Tauris, B.; Holm, P.B. Iron transport, deposition and bioavailability in the wheat and barley grain. Plant Soil 2009, 325, 15-24.

42. Costello, A.J.R.; Glonek, T.; Myers, T.C. 31P nuclear magnetic resonance-pH titrations of myo-inositol hexaphosphate. Carbohydr. Res. 1976, 46, 159-171.

43. Reddy, N.R. Occurrence, Distribution, Content, and Dietary Intake of Phytate. In Food Phytates; Reddy, N.R., Sathe, S.K., Eds.; CRC Press: Boca Raton, FL, USA, 2002.

44. Lott, J.N.; Ockenden, I.; Raboy, V.; Batten, G.D. Phytic acid and phosphorus in crop seeds and fruits: A global estimate. Seed Sci. Res. 2000, 10, 11-33.

45. Saxholt, E.; Christensen, A.T.; Møller, A.; Hartkopp, H.B.; Hess Ygil, K.; Hels, O.H. Danish Food Composition Databank, Revision 7; Department of Nutrition, National Food Institute, Technical University of Denmark: Lyngby, Denmark, 2008. Available online: http://www.foodcomp.dk/ (accessed on 28 March 2013).

46. Pantopoulos, K.; Porwal, S.K.; Tartakoff, A.; Devireddy, L. Mechanisms of mammalian iron homeostasis. Biochemistry 2012, 51, 5705-5724.

47. Council, N. Nordic Nutrition Recommendations 2004: Integrating Nutrition and Physical Activity; Nordic Council of Ministers: Copenhagen, Denmark, 2005.

48. Lynch, S. The precision of in vitro methods and algorithms for predicting the bioavailability of dietary iron. Int. J. Vitam. Nutr. Res. 2005, 75, 436-445.

49. West, A.R.; Oates, P.S. Mechanisms of heme iron absorption: Current questions and controversies. World J. Gastroenterol. 2008, 14, 4101-4110.

50. Alagozlu, H.; Karakan, T. Probiotics are sensitive microorganisms: Lactobacillus can be affected by stomach acid, antibiotic, and bowel cleansing. Dig. Dis. Sci. 2012, 57, 2477-2478.

51. Dressman, J.B.; Berardi, R.R.; Dermentzoglou, L.C.; Russell, T.L.; Schmaltz, S.P.; Barnett, J.L.; Jarvenpaa, K.M. Upper gastrointestinal (GI) pH in young, healthy men and women. Pharm. Res. 1990, 7, 756-761. 
52. Malagelada, J.-R.; Go, V.L.W.; Summerskill, W.H.J. Different gastric, pancreatic, and biliary responses to solid-liquid or homogenized meals. Dig. Dis. Sci. 1979, 24, 101-110.

53. Bretti, C.; Cigala, R.M.; Lando, G.; Milea, D.; Sammartano, S. Sequestering ability of phytate toward biologically and environmentally relevant trivalent metal cations. J. Agric. Food Chem. 2012, 60, 8075-8082.

54. Ismail-Beigi, F.; Faraji, B.; Reinhold, J.G. Binding of zinc and iron to wheat bread, wheat bran, and their components. Am. J. Clin. Nutr. 1977, 30, 1721-1725.

55. Veiga, N.; Torres, J.; Mansell, D.; Freeman, S.; Domínguez, S.; Barker, C.J.; Díaz, A.; Kremer, C. "Chelatable iron pool": Inositol 1,2,3-trisphosphate fulfils the conditions required to be a safe cellular iron ligand. J. Biol. Inorg. Chem. 2009, 14, 51-59.

56. Šala, M.; Makuc, D.; Kolar, J.; Plavec, J.; Pihlar, B. Potentiometric and ${ }^{31} \mathrm{P}$ NMR studies on inositol phosphates and their interaction with iron(III) ions. Carbohydr. Res. 2011, 346, 488-494.

57. Sandberg, A.-S.; Andlid, T. Phytogenic and microbial phytases in human nutrition. Int. J. Food Sci. Technol. 2002, 37, 823-833.

58. McCance, R.A.; Widdowson, E.M. Phytin in human nutrition. Biochem. J. 1935, 29, 2694-2699.

59. Hoff-Jørgensen, E.; Andersen, O.; Nielsen, G. The effect of phytic acid on the absorption of calcium and phosphorus. 3. In Children. Biochem. J. 1946, 40, 555-557.

60. Sandberg, A.-S.; Andersson, H.; Kivistö, B.; Sandström, B. Extrusion cooking of a high-fibre cereal product. 1. Effects on digestibility and absorption of protein, fat, starch, dietary fibre and phytate in the small intestine. Br. J. Nutr. 1986, 55, 245-254.

61. Kivistö, B.; Andersson, H.; Cederblad, G.; Sandberg, A.-S.; Sandström, B. Extrusion cooking of a high-fibre cereal product. 2. Effects on apparent absorption of zinc, iron, calcium, magnesium and phosphorus in humans. Br. J. Nutr. 1986, 55, 255-260.

62. Sandberg, A.-S.; Andersson, H.; Carlsson, N.-G.; Sandström, B. Degradation products of bran phytate formed during digestion in the human small intestine: Effect of extrusion cooking on digestibility. J. Nutr. 1987, 117, 2061-2065.

63. Iqbal, T.H.; Lewis, K.O.; Cooper, B.T. Phytase activity in the human and rat small intestine. Gut 1994, 35, 1233-1236.

64. Sandberg, A.-S.; Andersson, H. Effect of dietary phytase on the digestion of phytate in the stomach and small intestine of humans. J. Nutr. 1988, 118, 469-473.

65. Lei, X.G.; Weaver, J.D.; Mullaney, E.; Ullah, A.H.; Azain, M.J. Phytase, a new life for an "old" enzyme. Annu. Rev. Anim. Biosci. 2013, 1, 283-309.

66. Greiner, R.; Konietzny, U. Phytase for food application. Food Technol. Biotechnol. 2006, 44, 125-140.

67. Lei, X.G.; Porres, J.M. Phytase enzymology, applications, and biotechnology. Biotechnol. Lett. 2003, 25, 1787-1794.

68. Phillippy, B. Stability of Plant and Microbial Phytases. In Food Phytates; Reddy, N.R., Sathe, S.K., Eds.; CRC Press: Boca Raton, FL, USA, 2001.

69. Pandey, A.; Szakacs, G.; Soccol, C.R.; Rodriguez-Leon, J.A.; Soccol, V.T. Production, purification and properties of microbial phytases. Bioresour. Technol. 2001, 77, 203-214. 
70. Lei, X.G.; Porres, J.M.; Mullaney, E.J.; Brinch-Pedersen, H. Phytase: Source, Structure and Application. In Industrial Enzymes; Polaina, J., MacCabe, A.P., Eds.; Springer: Heidelberg, The Netherlands, 2007; pp. 505-529.

71. World Health Organization. Safety Evaluation of Certain Food Additives. In WHO Food Additives Series: 67; WHO Press: Geneva, Switzerland, 2012.

72. Kraemer, K.; Steiger, G.; Wieprecht, T. Iron Fortification Nutritional Blend. EP 2166876 B1, 10 April 2013.

73. Schlemmer, U.; Jany, K.D.; Berk, A.; Schulz, E.; Rechkemmer, G. Degradation of phytate in the gut of pigs - Pathway of gastrointestinal inositol phosphate hydrolysis and enzymes involved. Arch. Anim. Nutr. 2001, 55, 255-280.

74. Troesch, B.; Egli, I.; Zeder, C.; Hurrell, R.F.; de Pee, S.; Zimmermann, M.B. Optimization of a phytase-containing micronutrient powder with low amounts of highly bioavailable iron for in-home fortification of complementary foods. Am. J. Clin. Nutr. 2009, 89, 539-544.

75. Sandberg, A.-S.; Hulthén, L.R.; Türk, M. Dietary Aspergillus niger phytase increases iron absorption in humans. J. Nutr. 1996, 126, 476-480.

76. Kemme, P.A.; Schlemmer, U.; Mroz, Z.; Jongbloed, A.W. Monitoring the stepwise phytate degradation in the upper gastrointestinal tract of pigs. J. Sci. Food Agric. 2006, 86, 612-622.

77. Phillippy, B.Q. Susceptibility of wheat and Aspergillus niger phytases to inactivation by gastrointestinal enzymes. J. Agric. Food Chem. 1999, 47, 1385-1388.

78. Yu, S.; Cowieson, A.; Gilbert, C.; Plumstead, P.; Dalsgaard, S. Interactions of phytate and myo-inositol phosphate esters (IP 1-5) including IP5 isomers with dietary protein and iron and inhibition of pepsin. J. Anim. Sci. 2012, 90, 1824-1832.

79. Brune, M.; Rossander-Hultén, L.; Hallberg, L.; Sandberg, A.-S. Iron absorption from bread in humans: Inhibiting effects of cereal fiber, phytate and inositol phosphates with different numbers of phosphate groups. J. Nutr. 1992, 122, 442-449.

80. Sandberg, A.-S.; Brune, M.; Carlsson, N.-G.; Hallberg, L.; Skoglund, E.; Rossander-Hulthén, L. Inositol phosphates with different numbers of phosphate groups influence iron absorption in humans. Am. J. Clin. Nutr. 1999, 70, 240-246.

81. Tang, J.; Leung, A.; Leung, C.; Lim, B.L. Hydrolysis of precipitated phytate by three distinct families of phytases. Soil Biol. Biochem. 2006, 38, 1316-1324.

82. Heubner, W.; Stadler, H. Über eine titration-methode zur bestimmung des phytins. Biochem. $Z$. 1914, 64, 432-437.

83. Latta, M.; Eskin, M. A simple and rapid colorimetric method for phytate determination. J. Agric. Food Chem. 1980, 28, 1313-1315.

84. Carlsson, N.-G.; Bergman, E.-L.; Skoglund, E.; Hasselblad, K.; Sandberg, A.-S. Rapid analysis of inositol phosphates. J. Agric. Food Chem. 2001, 49, 1695-1701.

85. Haraldsson, A.-K.; Rimsten, L.; Alminger, M.; Andersson, R.; Åman, P.; Sandberg, A.-S. Digestion of barley malt porridges in a gastrointestinal model: Iron dialysability, iron uptake by Caco-2 cells and degradation of $\beta$-glucan. J. Cereal Sci. 2005, 42, 243-254.

86. Sandberg, A.-S. Methods and options in vitro dialyzability; benefits and limitations. Int. J. Vitam. Nutr. Res. 2005, 75, 395-404. 
87. Argyri, K.; Theophanidi, E.; Kapna, A.; Staikidou, C.; Pounis, G.; Komaitis, M.; Georgiou, C.; Kapsokefalou, M. Iron or zinc dialyzability obtained from a modified in vitro digestion procedure compare well with iron or zinc absorption from meals. Food Chem. 2011, 127, $716-721$.

88. Fairweather-Tait, S.; Lynch, S.; Hotz, C.; Hurrell, R.; Beebe, S.; Bering, S.; Bukhave, K.; Glahn, R.; Hambidge, M.; Hunt, J.; et al. The usefulness of in vitro models to predict the bioavailability of iron and zinc: A consensus statement from the HarvestPlus expert consultation. Int. J. Vitam. Nutr. Res. 2005, 75, 371-374.

89. Laparra, J.M.; Glahn, R.P.; Miller, D.D. Different responses of Fe transporters in Caco-2/HT29-MTX cocultures than in independent Caco-2 cell cultures. Cell Biol. Int. 2009, 33, 971-977.

90. Sandberg, A.-S. The use of Caco-2 cells to estimate Fe absorption in humans-A critical appraisal. Int. J. Vitam. Nutr. Res. 2010, 80, 307-313.

91. Haraldsson, A.-K.; Veide, J.; Andlid, T.; Alminger, M.L.; Sandberg, A.-S. Degradation of phytate by high-phytase Saccharomyces cerevisiae strains during simulated gastrointestinal digestion. J. Agric. Food Chem. 2005, 53, 5438-5444.

92. Yun, S.; Habicht, J.-P.; Miller, D.D.; Glahn, R.P. An in vitro digestion/Caco-2 cell culture system accurately predicts the effects of ascorbic acid and polyphenolic compounds on iron bioavailability in humans. J. Nutr. 2004, 134, 2717-2721.

93. Sanz-Penella, J.M.; Laparra, J.M.; Sanz, Y.; Haros, M. Assessment of iron bioavailability in whole wheat bread by addition of phytase-producing bifidobacteria. J. Agric. Food Chem. 2012, 60, 3190-3195.

94. World Health Organization. Assessing the Iron Status of Populations; WHO Press: Geneva, Switzerland, 2007.

95. Lynch, S.R. Why nutritional iron deficiency persists as a worldwide problem. J. Nutr. 2011, 141, 763S-768S.

96. Casgrain, A.; Collings, R.; Harvey, L.J.; Hooper, L.; Fairweather-Tait, S.J. Effect of iron intake on iron status: A systematic review and meta-analysis of randomized controlled trials. Am. J. Clin. Nutr. 2012, 96, 768-780.

97. Zimmermann, M.B.; Molinari, L.; Staubli-Asobayire, F.; Hess, S.Y.; Chaouki, N.; Adou, P.; Hurrell, R.F. Serum transferrin receptor and zinc protoporphyrin as indicators of iron status in African children. Am. J. Clin. Nutr. 2005, 81, 615-623.

98. Troesch, B.; van Stujivenberg, M.E.; Smuts, C.M.; Kruger, H.S.; Biebinger, R.; Hurrell, R.F.; Baumgartner, J.; Zimmermann, M.B. A Micronutrient powder with low doses of highly absorbable iron and zinc reduces iron and zinc deficiency and improves weight-for-age Z-scores in South African children. J. Nutr. 2011, 141, 237-242.

99. Bokhari, F.; Derbyshire, E.; Li, W.; Brennan, C.S.; Stojceska, V. A study to establish whether food-based approaches can improve serum iron levels in child-bearing aged women. J. Hum. Nutr. Diet. 2012, 25, 95-100.

100. Conway, R.E.; Geissler, C.A.; Hider, R.C.; Thompson, R.P.H.; Powell, J.J. Serum iron curves can be used to estimate dietary iron bioavailability in humans. J. Nutr. 2006, 136, 1910-1914. 
101. Zhang, H.; Onning, G.; Öste, R.; Gramatkovski, E.; Hulthén, L. Improved iron bioavailability in an oat-based beverage: The combined effect of citric acid addition, dephytinization and iron supplementation. Eur. J. Nutr. 2007, 46, 95-102.

102. Shockravi, S.; Almgren, A.; Carlsson, N.-G.; Sandberg, A.-S. Dephytinisation of Sangak and Barbari bread made from different extraction rate flours increases iron and zinc bioaccessibility in Caco-2 cells. Int. J. Food Sci. Technol. 2012, 47, 2252-2258.

103. Sanz-Penella, J.M.; Frontela, C.; Ros, G.; Martinez, C.; Monedero, V.; Haros, M. Application of bifidobacterial phytases in infant cereals: Effect on phytate contents and mineral dialyzability. J. Agric. Food Chem. 2012, 60, 11787-11792.

104. Akhter, S.; Saeed, A.; Irfan, M.; Malik, K.A. In vitro dephytinization and bioavailability of essential minerals in several wheat varieties. J. Cereal Sci. 2012, 56, 741-746.

105. Hurrell, R.F.; Reddy, M.B.; Juillerat, M.-A.; Cook, J.D. Degradation of phytic acid in cereal porridges improves iron absorption by human subjects. Am. J. Clin. Nutr. 2003, 77, 1213-1219.

106. Haros, M.; Rosell, C.M.; Benedito, C. Fungal phytase as a potential breadmaking additive. Eur. Food Res. Technol. 2001, 213, 317-322.

107. Sanz-Penella, J.M.; Tamayo-Ramos, J.A.; Sanz, Y.; Haros, M. Phytate reduction in bran-enriched bread by phytase-producing bifidobacteria. J. Agric. Food Chem. 2009, 57, 10239-10244.

108. Hellström, A.M.; Almgren, A.; Carlsson, N.-G.; Svanberg, U.; Andlid, T.A. Degradation of phytate by Pichia kudriavzevii TY13 and Hanseniaspora guilliermondii TY14 in Tanzanian togwa. Int J. Food Microbiol. 2012, 153, 73-77.

109. Shilpa, K.S.; Lakshmi, A.J. Comparison of enhancement in bioaccessible iron and zinc in native and fortified high-phytate oilseed and cereal composites by activating endogenous phytase. Int. J. Food Sci. Technol. 2012, 47, 1613-1619.

110. Zhao, F.-J.; Shewry, P.R. Recent developments in modifying crops and agronomic practice to improve human health. Food Policy 2011, 36, S94-S101.

(C) 2013 by the authors; licensee MDPI, Basel, Switzerland. This article is an open access article distributed under the terms and conditions of the Creative Commons Attribution license (http://creativecommons.org/licenses/by/3.0/). 